\title{
学内各教室に分散している 資料目録の諸問 題
}

\section{小 野 和 夫*}

\section{1.はじめに}

医学図書館が日常取扱つている文献情報には，Dissertation なども稀にあるが，主に Serial，および Monograph 所載の情報が 大部分を占めていることは疑いな い。Serial 所戴情報の検索には各種の二次資料が用意さ れて抢り，さらに積極的な情報提供，たとえば SDl service などの手法も多角化して来て, その速報化の進捗と 共に日々充足の方向に向いつつあるといえるであ万う。 さらに，そのDRに関しても国内的には伝統ある本協会 のネット・ワーク, 就中テレックス網の拡大等により今 後益々そのスピード・アップも期待出来る情勢にある。

一方 Monograph 所載の文献情報については, 新着書 目録や出版書目録等による部分的な伝達手段をもつにす ぎず，Serial 所載論文が広汎なさまざまな伝達手段を持 っているのに比較すれば遥かに弱体であることは拒めな い。少なくとも当館では，そのリクエストの多寒および 緊急度にも上るが, 利用者からの要求があってはじめて 館員がカード目録や二次資料を検索した上で，利用者に その情報（書誌的事項，所蔵の有無および入手の手段な ぞ）を提供するという旧来の域を脱してはいない。

Monograph 所載の情報に対する利用者の要求は，た と兊ば Theory 等について，研究者が読んだ論文の引 用文献を辿って要求される場合が多く，それは論文の Historical background 等に引用され，または確認する ための要求であることが多い。新らしい知見の公表であ る原著論文等が一次資料といわれるのに対し Monograph の多くが数多くの先行原著論文の上に構成されてい るところから一般に二次資料群と見做されており，した

\footnotetext{
* Kazuo ONO, 東北大学医学図显馆
}

がって Monograph は Serial ほどに情報提供の緊急度 が需められることは稀ともいえようが，現実には次第に 実数が增加してきている。図書館は，研究者が必要とす る情報を最大の能力を発揮してて提供しなければならない が，そのためには医学拉よびその関連領域を広くカバー するだけの網羅的な蔵書群がその資料源として不可欠で あり，さらにそれは常に拡大拡充されて行かなければな らない。しかし，1医学図書館がその抱えている研究者 が增加し, 研究領域と研究方法が抾散すればする程, そ の全ての要求に応えることが到底不可能であることは言 うまでもない。本稿では, 当館が激增する研究者の要求 に集書と目録の面で如何に対処しょうとするのか，その 中で各教室所蔵図書の目録がどんな役割を果し得るのか を，試（私）案の域を出るものではないが，計画中の作 業をも含みながらその一端を紹介してみたい。

\section{2. 教室備付図書の現状}

東北大学医学図書館は, 医学部医学科 18 教室, 附属 病院 15 科 6 部, 2 分院 8 科, 2 研究所 18 部門, 薬学科 9 教室, 歯学部 11 教室, 同附属病院 8 科 2 部, および 4 附属学校等, 合計 99 セクションの図書行政を所掌し, 44 年度末で 169,847 冊を超える医学関係図書 (原簿記入 省略扱図書を含まず）を所蔵するが，その $60 \%$ は医学 図書館以外の前記教室または図畫室に備付け，すなわち 長期貸出しされており，当館は残余の $40 \%$ を架蔵して いるにすぎず，その殆んどは医学雑誌と二次資料であ り, 単行書の所蔵冊数は基礎的或いは共通分野のものお よび学生用図書を含め約 8,000 冊にすぎない。当館には ロケーションを付した分類扣よび著者名目録を維持して 照会に応じ, 館内架蔵のものは館内で, 教室備付けのも 
のは各教室において閲覧または借用できる仕組みになっ ている。昭和 44 年度の年間増加冊数は 5,595 冊である が, うち 2,795 冊は雑誌の完結受入であり, 単行書の純 増は和書 1,435 冊, 洋書 1,365 冊にすぎず, 網羅的収集 には遥かに程遠いのが現状である。各教室または図書室 には，受入済の図書を貸付ける際その印刷カードを添付 乙，それが各教室毎の分類および著者名目録として編成 され，教室内での検索用に使用されている。

\section{3. 現方式での問題点}

年間 3,000 冊約 1,300 万円にのぼる単行書費は図書館 図書費によって買われるが, 図書費の大半は各講座研究 費からの振替予算によって構成されており，これについ ては図書館は選択の権限を持たない。僅かに参考資料の ための図書館資料費, おょび学生用図書費について直接 的選択の責任を持っているにすぎない。図書館は種々の 出版情報を各教室に提供し, それにより各教室から出さ れた図書購入請求票により発注, 受入, 整理, 貸付を行 なっており, 書誌調整は発注前の重複調査等の段階でそ の一部が行なわれているにすぎない。したがって, 総額 では 3,800 万円の図書費を㩑しながら，単行書の収集で は各種の重要図書の膨大な欠落を生ずる一方, 過剩な重 複も生ずる結果となっている。また，各教室の目録は自 らの架蔵図書のカードだけで編成されているためその教 室にない図書については図書館に照会しなければ検索が 不可能であり，専ら管理的用途のみに使用されている例 が多い。この現状は, 図書館への振替後であっても, 図 書費には講座研究費としての潜在的主権が随伴し, 図書 館にはそれを調整する強力な権限が附与されていないこ とに根ざしているといってよい。当館に限らず，国立ま たは公立大学の図書館は, 多かれ少なかれこの種の障壁 の前で苦闘しておられるに違いないと考えられる。

\section{4. 改 革 の 構 想}

医学図書館がその全藏書を集中的汇保蔵・管理・運用 することは望ましいことではあるが，一方研究用の図書 を身近に置いておきたいといら研究者の要望もまた合理 的規範の中で存続させてゆかなければならない。当館は すで新臨床研究棟への移転に際し，臨床各科よりその 備付図書の中から 21,000 冊を臨時書庫に返戻を行ない つつあり，今後もさらに段階的に集中化を目指してい る。これは数年先に建築を予定している新図書館完成時 までの間化着実に行なわれるであうう。すなわち，当館
は近い将来での集中化を目指しながらも，現寄には調整 された分散方式を採らざるを得ないことになる。

では, その時点での教室備付図書群はどんな性格・特 色を持つべきであろうか。各教室は各々の専門領域に属 する図書を可能な限り網羅するよう調整されなければな らない。すなわち，教室毎には各々専門領域のコレクシ ョンとしての性格を持ちながら, 医学関係部局総体とし ては，予算的制約レベル内での完結された医学書拉よび 関連図書のコレクションを形成しなければならない。こ れら制約下においての書誌調整は, 各教室からの請求段 階で「図書購入請求票」にグレードを付し，さらに印刷 カード配布との組合わせによって可能となる。

請求票グレード
$\mathrm{A}$ ：図書館または他教室に所蔵されていても，是非 備付けたい。
B：図書館または他教室にあれば購入の必要なし, なければ備付ける。
C : 出来れば図書館に備付けて欲しい。

A は現在の研究上不可欠の図書であり, その領域の専 門書であることが多い。Bは他領域の図書であることも 多いが，現在の研究にとり必要度の高い図書である。C は関連領域の図書であっても関心度の高い図書であっ て，将来の潜在需要図書であることを意味し，学内のい ずれかに所蔵されていればよい。就中医学図書館にある ことが利便度が高い図書館は，Aの図書はそのまま受入 れ，Bは図書館または他教室にない場合は受入れし，あ る場合はそのカードを教室に配布する。Cについては， 図書館が判定して館自体の図書費により購入し，そのカ 一ドを教室に配布する。その際同一書についての要求が 数教室から出された場合は優先して購入する。Cの請求 は各教室の図書費の枠とは無関保に請求できるので, 関 連領域の図書の収集上では有力なデータとなり得る。特 に，教室内での選定から脱落した図書を救う途を拓くこ とになることは疑いなく，そのためには図書館自体の図

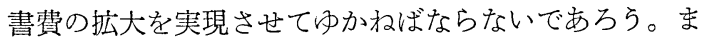
た，教室或いは研究者からの請求を活㳊にするよら，今 まで以上にあらゆる出版情報を不断に且つ適切に供給乙 なければならないし，そのためには誰が，ぞんな研究 をぞのような方法で行なっているかを常に掌握してお かなければならない。さらに，主要な医学書で受入れす ることが出来なかった図書を調查し，公表する努力も必 要となる。一方, 医学関係部局受入図書の印刷カードに ついて, 各教室からその関連分野の希望を当館が使用し 
ている NLM 分類表の主綱レベル採り，受入の都度その 印刷カードを希望教室に配布する。配布カードはその教 室のカードと一括して編成され, 次の請求時の選択の際 に有効な判断のデータとなる。すなわち,グレードBの 希望書が図書館や他教室に既に䚚付けてあることを知れ ばさらに請求するまでもなく，またグレードAに属する 図書を，配布された印刷カードの中から発見することも あり得る。必要な図書が，必要な䉪所に，必要な度合に 応じて必要なだけ脱洩なく，また過剩な重複もなく供付 けられ利用に供されることは，網羅的収集に次第に近つ きながら，然かも限られた予算の枠内での効用最大を実 現することになるであろう。各教室には，次第にその専 門書と関連図書の書誌（カード目録）と，研究上の要請 を満足しつつ関連領域の図書を包含しながらその教室の 分野の専門書が調整されて集中し, 特色あるコレクショ ンを形成することになる。

本学は, 農学部に農芸化学科, 食糧科学科, 畜産学 科, 理学部に生物学科, 化学科, 他に農学䂗究所等の関 連部局があり, 年々相当数の図書を受入れており所蔵冊
数も多く, これら学内図書は当館の後背的資料群であっ て, 学内相互貸借が頻繁に行なわれている。本学附属図 書館 (本館) は，既に 10 年前よりその所掌部局の全受 入図書についてのユニット・カードの有料配布を実施し ているが，部局単位の配布方式（たとえば，農学部が農 学研究所の全受入図書のカード配布を受ける）であるた め, 当館が現方式のまま印刷カードの配布を受ければ， 必要のない図畫のカードを多分に含んだ大量のカードが 流入することになり，その運用上多大の経費と労力を要 することになる。したがって，主題別配布方式への転換 を推進して，医学関連領域とオーバーラップする領域に ついての限定されたカード配布を受けることが望ましい と考えられる。これにより, 書誌調整が当館と各教室間 だけではなく，これを超えて全学的に及ぶことにもな り，その資料面および予算面での効率化に貢献するに違 いない。各室の目録は，従来のように単なる所蔵目録或 いは管理的目録としてではなく，各々の専門分野の活き た書誌として医学図書館の目録とともに体系化されてゆ くことになろら。

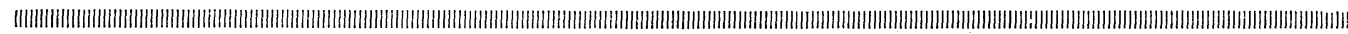

\section{〈表紙紹介〉大阪医科大学医学図書館}

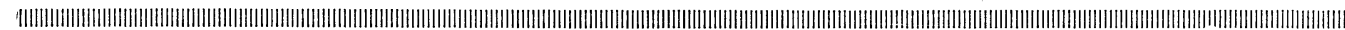

本学は昭和 2 年に大阪高等医学専門学校として発足 し, 昭和 21 年に旧制大学, 昭和 27 年には新制大学とな り，昭和 40 年には進学課程も設置されて 現在に至って いる。図書館も本学開校と同じに設立されたが，当初は 小規模なもので, 蔵書約数千冊で本学本館の 3 階にあ り，図書室と呼ぶ方がふさわしいものであった。

昭和 31 年に図書館が新築され，館長の努力により蔵 書数も大幅に増加した。4 階建で閲覧室 $130 \mathrm{~m}^{2}$, 事務室 $30 \mathrm{~m}^{2}$, 書庫 $277 \mathrm{~m}^{2}$ ，延面積は $490 \mathrm{~m}^{2}$ で，事務室・閲 覽室を 1 階におき，書庫は 2 階以上になっている。図書 館創立当時と現在の資料を比較すると，下記のようにな
る。

$\begin{array}{lrrr} & \text { 蔵書数 } & \text { 洋雑誌 } & \text { 和雑誌 } \\ \text { 昭和 } 30 & 12,000 \text { 冊 } & 73 \text { 種 } & 164 \text { 種 } \\ \text { 炤和 } 45 & 61,000 \text { 冊 } & 410 \text { 種 } & 357 \text { 種 }\end{array}$

現在本館の他に進学課程と研修医用にそれぞれ分室が ある。館員は女子 7 名，らち 2 人は進学課程である。近 日中には図書館運営委員会が正式発足する予定であり, 活発な動さが期待される。

現在の建物は不備な点が多く，手狭なので，第 2 期工 事が一日も早く始まることを待っている。 